This is the final peer-reviewed accepted manuscript of:

Jingjing Zhang, Riccardo Leoncini, Yingyi Tsai, Intellectual property rights protection, labour mobility and wage inequality, Economic Modelling, Volume 70, 2018, pages 239-244.

ISSN 0264-9993

https://doi.org/10.1016/j.econmod.2017.11.006.

The final published version is available online at:.

https://www.sciencedirect.com/science/article/pii/S0264999317309562

Rights / License:

The terms and conditions for the reuse of this version of the manuscript are specified in the publishing policy. For all terms of use and more information see the publisher's website.

ELSEVIER https://www.elsevier.com/about/policies

This item was downloaded from IRIS Università di Bologna (https://cris.unibo.it/)

When citing, please refer to the published version. 


\title{
Intellectual property rights protection, labour mobility and wage inequality
}

\author{
Jingjing Zhang ${ }^{\text {a }}$, Riccardo Leoncini ${ }^{\text {b,d }}$, Yingyi Tsai ${ }^{\text {c, * }}$ \\ ${ }^{a}$ Institute for Social and Economic Research, Nanjing Audit University, China \\ ${ }^{\mathrm{b}}$ University of Bologna, Italy \\ ${ }^{\mathrm{c}}$ Department of Applied Economics, National University of Kaohsiung, Taiwan, ROC \\ ${ }^{\mathrm{d}}$ Freiburg Institute for Advanced Studies (FRIAS), University of Freiburg, Freiburg im Breisgau, Germany, IRCrES-CNR, Milan, Italy
}

\begin{abstract}
A B S T R A C T
By focusing on the role of intellectual property rights (IPRs), this paper contributes to the literature on determinants of skilled-unskilled wage inequality. We use a two-sector general equilibrium model of a small open economy that produces a normal and an innovation good. We show that in the presence of cross-border differences in IPRs and consequent mobility of skilled labour, the impact of IPRs on skilled-unskilled wage inequality can be broken down into a revenue effect and an output effect. We find that a stronger IPRs regime in the source country reduces its skilled-unskilled wage inequality. However, if the output effect is stronger than the revenue effect, an increase in the recipient country's IPRs protection can contribute to an increase in wage inequality in the source country. Our results confirm the importance of institutional factors, such as the IPRs protection, in addressing the skilled-unskilled wage inequality.
\end{abstract}

Keywords:

IPRs protection

Wage inequality

Labour mobility

\section{Introduction}

Rising wage inequality between the skilled and the unskilled workers had spurred extensive discussions since the late 1970s (e.g., OECD, 2011; UNDP, 2013; ILO, 2016; World Bank, 2016). This discussion focused mainly on structural changes that were driven by the increasingly connected global economy associated with the rapid spread of digital technologies. In the wake of growing outsourcing activities, the unskilled workers in the globe face an unprecedented pressure. Digital technologies replace job opportunities that were used to be performed by the unskilled workers, while complementing jobs and tasks performed by the skilled workers. Subsequently, highly skilled workers are generally rewarded with greater compensation, which, in turn, causes a negative impact on income distribution between the skilled and the unskilled labour (OECD, 2011; World Bank, 2016). For instance, the proportion of routine (low-skilled) labour in the US declined from $39 \%$ to $23.6 \%$ from 1968 to 2013, while that of the non-routine (skilled) labour saw an increase from $24.4 \%$ to $33.6 \%$ during the same period (Eden and Gaggl, 2014). Further evidences also confirm these findings for several countries with different levels of technological progress (e.g. Srour et al., 2013; Marouani and Nilsson, 2016; Gaggl and Wright, 2017). This trend appears to be fairly common in both the developed and the emerging countries, in contrast to the principle of comparative advantage (Berman and Machin, 2000; Kremer and Maskin, 2006; Maskin, 2015).

Although job markets in the highly technological-diffused countries generally are in favour of the skilled workers, it is not always the case that technological changes are skill-biased, when, in particular, we take into account of the degree of substitutability and complementarity between technology and labour (Saint-Paul, 2008). Acemoglu (2002) emphasizes that institutions and international trade can influence the patterns of wage inequality. ${ }^{1}$ Indeed, institutional factors, such as the regime of intellectual property rights (IPRs) protection, have been considered alongside technology since they have facilitated in shaping the different patterns of international flows of skilled migrants, which, in turn, affect wage inequality.

The strength of IPR regimes across borders can constitute a powerful instrument through which the direction of technology development is affected. Higher IPRs protection might induce a higher level of

\footnotetext{
* Corresponding author.

E-mail addresses: njustzjj@gmail.com (J. Zhang), riccardo.leoncini@unibo.it (R. Leoncini), yytsai@nuk.edu.tw (Y. Tsai).

1 A set of institutional mechanisms, which are outside this paper's scope, are those that contribute to determining the wage levels, such as minimum wage law, unionization, non-

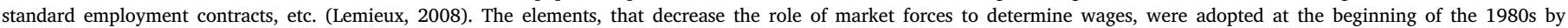

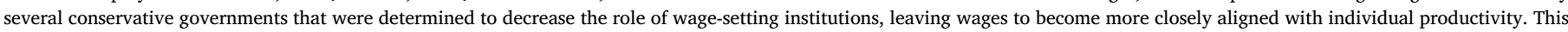

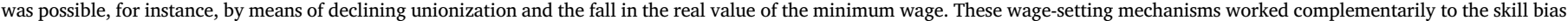
technical change hypothesis (Kristal and Cohen, 2015).
} 
technological change, which, in turn, would increase the demand for skilled workers. Subsequently, this impacts on the mobility of the skilled labour with implications for wage inequality. We consider the strength of IPRs regime as an important determinant of a country's level of institutional strength and, thus, a crucial element while addressing age differentials as a result of the changes in IPRs regimes.

To the best of our knowledge, the role of IPRs protection in determining the rate and direction of wage inequality has not been thoroughly analysed. This paper aims to contribute to fill this gap. We investigate the effects of tightening up the protection of IPRs on skilled migration and income inequality in the global economy. We do so by addressing the following fundamental research question: How do IPRs protections affect the skilled labour mobility and wage inequality? We develop a small open economy model in which the mobility of skilled labour across international boundaries occurs due to the changes in the level of IPRs protection. We show that an increase in IPRs protection in the source country narrows down the skilled-unskilled wage inequality. However, an increase in the recipient country's IPRs protection, leads to an increase in skilled-unskilled wage inequality in the source country, but only when the associated output effect dominates the revenue effect.

The paper is structured as follows. Section 2 reviews the relevant literature. Section 3 contains the basic model, the results on labour mobility and implications for wage inequality. Section 4 summarizes our findings and Section 5 concludes.

\section{Literature review}

It has long been acknowledged (Rosen, 1981) that technology is a key driver of changes in wages and income (Saint-Paul, 2008; Goldin and Katz, 2009; Kurokawa, 2014). The skill-biased technological change hypothesis is based on the empirical evidence of a positive relationship between the diffusion of the use of computers, in particular on job sites, and wage differentials between workers with low and high skills respectively (Katz and Murphy, 1992; Autor et al., 1998). In a recent empirical study, Mallick and Sousa (2017) found that technology is correlated to the skill premium and the demand for skilled labour, especially in the science-based and production-intensive industries.

Skilled migration has long been understood to be an important indicator of technological change within the context of international relations. A large literature has suggested that skilled labour provide new invention and the emigration of skilled labour alters a country's capacity to be innovative. Grubel and Scott (1966) first used the term "brain drain" to explain the impact of the trend of skilled migration from developing countries in reducing the innovative capacity of source countries (Commander et al., 2004). In a recent study, Agrawal et al. (2011) found that the emigration of skilled labour does in fact weaken local knowledge networks (i.e., the brain-drain effect) but it also it allows innovators to retain their access to knowledge accumulated abroad (i.e., the brain-bank effect).

A number of studies have attempted to identify the determinants of skilled-unskilled wage inequality based on the mobility of workers and other factors. For example, Li and Zhou (2013) examined the impact of migration on wage inequality in the host country by focusing on the remittance of migrants; similar studies include Zhang (2012, 2013), Anwar (2010), Anwar et al. (2013), Anwar and Sun (2015) and Pi and Zhou (2012). While most of the literature takes market forces into account, few studies have explicitly considered the link between the institutional level and skill premium. Pi and Zhou $(2014,2015)$ investigated the impact of institutions' quality on wage inequality. To date, the literature has mainly focused on the role of institutions in general terms, without specifying how each institution impacts inequality. We focus on IPRs as they are the most important institutional instruments that governments can enforce structural change across the institutional landscape of a country.

Only recently, a number of studies have explored the link among IPRs protection, skilled labour mobility and innovation, starting from the literature on the relationships between IPR protection and North-South trade (Lai and Qiu, 2003; Grossman and Lai, 2004) and IPR protection and outsourcing/offshoring (Antras and Helpman, 2004). This literature emphasizes the possible benefits from a government's relative incentive to provide patent protection that typically increases with its relative endowment of human capital (Grossman and Lai, 2004), and the benefits that both North and South can derive from harmonisation of its IPR standards; this together with the North liberalising the goods market (Lai and Qiu, 2003). With regard to outsourcing/offshoring, this has been shown to impact the skill premium in a similar way to technological change. In fact, it directly affects the wages of unskilled workers, thus increasing wage inequality; although when it happens in the service sector, it has been shown to affect skilled labourers as well (Bottini et al., 2007). Mondal and Gupta (2008) analysed the conditions through which, within a North-South model, the strengthening of IPR protection may favour innovation in the South and South-North migration. McAusland and Kuhn (2011) shown how governments use IPRs policy as a tool to attract the creators of intellectual property, a concept referred to as "bidding-for-brains"; they also identified an opposing force that reduces the incentives of a country facing brain drain to protect IPRs. This so-called "expatriate brains" effect occurs because innovations are heterogeneous in their usefulness to different countries. The assumption draws on work by Diwan and Rodrik (1991) that North and South may have differing technological needs, making innovations abroad less relevant to the country of origin. They shown the negative effect of brain drain on IPRs are dominant in small or lagged economies, whereas the positive effect through a bidding war is more significant for advanced countries. This is essentially due to the large distance to the frontier regarding IPR laws in developing countries that hinders their use of IPRs protection to retain their brains. Chu and Peng (2011) developed a two-country R\&D-based growth model in which the strengthening of patent protection in either country increases economic, growth as well as income inequality in both countries. They found that strengthening patent protection in developing countries increased global economic growth but also worsened global income inequality. Finally, Naghavi and Strozzi (2015) shown that IPRs moderate the relationships between migration and innovation because they provide the knowledge required to stimulate domestic innovation in developing countries. The strength of IPRs protection also determines whether migration results in brain drain or not.

Public policies might therefore, influence the relationships between technology and labour and drive more equitable results. A proper market for IPRs is thus seen as crucial by the OECD, which highlights patent policies as one of the main elements to strengthen innovation and technological changes in both developed and developing countries (OECD, 2013; 2014a, 2014b). IPRs are thus an important institutional element, the strength of which impacts innovation and the mobility of inventors, which, in turn, leads to changes in the wage premium for skilled labour. ${ }^{2}$

Almost all the above-mentioned literature focuses on the welfare effect on skilled labour, such as change in skilled labour income, by exploring the direct impact of IPRs, or how IPRs lead to spill-overs and in turn impact on skilled labour's income. One important issue that remains unresolved is the extent to which the IPRs regime affects the wages of unskilled labour and the return to capital, and, thus the wage inequality of an economy. These questions can adequately be studied within a general equilibrium analysis, which is the basic framework of this study and will be addressed in the next paragraph.

\footnotetext{
${ }^{2}$ For instance, the Office of the U.S. Trade Representative (USTR) releases 'Special 301 Reports' identifying its trading partners' protection and enforcement of IPR. In the latest list, 2016 Special 301 list, some emerging countries such as China and India are in the Priority Watch List (PWL), which indicates the poor enforcement of IPR in such countries. Coincidently, these countries are recognized as the main sources of emigration of highly educated labour. There is clear evidence for a growing brain drain from developing countries since 1970s (Docquier and Rapoport, 2008).
} 


\section{The model}

We consider the labour mobility between two countries: the source country $(S)$ and the recipient country $(R)$. The source country produces two final goods: innovation goods $(Y)$ and normal goods $(X)$. Following the already cited literature and the wide belief that skilled labour serve as inventors because they have undergone training and technical knowledge accumulation that is necessary for creative activities, we consider the innovation good, which is akin to a non-congestible public good, to have been produced by skilled labour $\left(L_{s}\right)$ and capital $(K)$. The normal good, which can be viewed as a manufactured or/an agricultural good, is produced by unskilled labour $\left(L_{u}\right)$ and capital $(K)$. The production function exhibits constant returns to scale in the production of $X$ and $X$ is the numeraire. The production of the innovation sector is characterized by monopolistic competition because of the fixed cost and substitutable products.

We assume that the innovation sector is capital intensive compared to the normal sector. ${ }^{3}$ According to the existing literature on IPRs and innovation (for example McAusland and Kuhn, 2011), inventors can sell their innovation products to the customers of source country $S$ as well as recipient country $R$. The effective market size of $S$ and $R$ are $N=$ $\left(L_{S}+L_{U}\right) * b(I)$ and $N^{*}=\left(L_{S}^{*}+L_{U}^{*}\right) * b\left(I^{*}\right)$, respectively, where variables with * refers to country $R$ and $b$ is an increasing function of GDP per capita $(I)$. In addition, we assume the inventors make up only a small share of the population. Therefore, the change in effective market size and capital endowment caused by skilled immigrants is negligible. As the intellectual property can be replicated at a zero cost, government plays a role in IPR protection.

We assume that the representative customer is characterized by a first-order homogeneous utility function, which indicates a constant share of income spent on the innovation products. Therefore, the revenue of the inventors from each unit of an innovation good $(M)$ is as follows:

$M=N \omega p+\tau N^{*} \omega^{*} p$

where $\tau$, which is less than 1 , is the "home bias" of innovation, ${ }^{4} \omega$ is the IPRs protection, measuring the probability that the inventor has full monopoly power over the sale of her product in the country $S$; $w^{*}$ is the IPRs protection in $R .^{5}$

It is notable that, different to McAusland and Kuhn (2011), who consider that the inventor makes decisions on innovative output according to her monopolistic power over a specific product, we simply assume that each inventor produces one variety of innovation product that is indivisible. Therefore, in a typical monopolistic competition market, the price of innovation product $(p)$ is determined by the number of available products $\left(L_{S}+L_{S}^{*}\right)$ which is a constant no matter how the skilled labour allocates it and price elasticity of demand is externally decided. This simplification allows us to focus on the production inputs adopted by different industries and to investigate the impact of IPRs schemes on wage inequality.

The principal purpose of our study is to investigate the impact of IPRs schemes on wage inequality via skilled labour mobility. In order to focus on this point, we made the assumption that the supply of unskilled labour

\footnotetext{
${ }^{3}$ This implies that $\theta_{K}^{X}<\theta_{K}^{Y}, \xi_{X}^{K}<\xi_{X}^{U}$ and $\xi_{Y}^{S}<\xi_{Y}^{K}$, where $\theta_{i}^{j}$ is the amount of factor $i$ per unit of sectorjoutput, and $\xi_{j}^{i}$ is the factor share of $i$ in sector $j$.

${ }^{4}$ Following McAusland and Kuhn (2011), we assume home bias takes the form of an iceberg transportation cost and $\tau$ is the fraction of the good's value that survives transported to a foreign market.

${ }^{5} \omega=0$ implies no IPR protection, whereas $\omega=1$ means full IPR protection. The inventors will withdraw from the markets if $\omega$ is lower than a threshold value $\underline{\omega}$ which assures marginal revenue cover the marginal cost. Because innovation products, for example software, are usually tangible and characterized by low a marginal cost, the threshold value $\omega$ can be set at a very low level. Hence in this study, we consider the situation that is most possible where $\omega \geq \underline{\omega}$, i.e., producers of innovation products stay in the market.
}

and capital are exogenous and not directly related to IPRs schemes. Capital is fully mobile across the two sectors. However, the supply of skilled labour in country $S$ is determined by alternative IPRs schemes, among other factors such as social welfare, given the possibility of migration. Depending on the level of IPRs protection and emigration cost, a skilled worker in country $S$ who has the capacity to invent, may emigrate. The decision to emigrate depends on the gap, $g\left(\omega, \omega^{*}\right)$ between the expected revenue from migrating $\left(M^{*}\right)$ and staying in the home country $(M)$ and emigration cost. The gap between expected revenue is shown by Eq. (2):

$g\left(\omega, \omega^{*}\right)=M^{*}-M=(1-\tau) p\left[N^{*} \omega^{*}-N \omega\right]$

Emigration costz, which involves physical and psychological costs, varies among individuals. Emigration cost follows a general distribution, i.e., $z \sim[0, \bar{z}]$ with the cumulative probability density function of $F(z)$, where $\bar{z}$ is the maximum possible cost (McAusland and Kuhn, 2011). Consider the case where $g\left(\omega, \omega^{*}\right)>0$ and hence the expected revenue from migrating is higher than the revenue from not migrating: for $g()<.\bar{z}, F\left[g\left(\omega, \omega^{*}\right)\right]$ is the probability of emigration, which is monotonically increasing with the expected gap revenue ${ }^{6}$; it is obvious that an increase in source country's IPR protection will reduce the expected revenue gap (i.e., $\partial g / \partial \omega<0)$, which will reduce the outflow of skilled labour (i.e., $\left.\frac{d F}{d g} \frac{\partial g}{\partial \omega}<0\right)$, while an increase in the recipient country's IPR protection will increase the expected revenue gap (i.e., $\partial g / \partial \omega^{*}>0$ ), which will increase the outflow of skilled labour (i.e., $\frac{d F}{d g} \frac{\partial g}{\partial \omega^{*}}>0$ ) from $S$ to $R$. Therefore, the size of the remaining skilled labor in country $S$ can be written as $(1-F) * L_{S}$.

The output of the innovation sector is determined by the following zero profit condition. The right-hand side of equation (3) is the unit price.

$w_{S}+a_{K Y} r=N p \omega+\tau N^{*} p \omega^{*}$

where $w_{S}$ is skilled wage and $r$ is return on capital; $a_{i j}$ is the coefficient of production, i.e., the factor $j$ required to produce one unit of outputi.

The output of the normal sector is determined by the zero-profit condition as follows:

$a_{U X} w_{U}+a_{K X} r=1$

where $w_{U}$ the unskilled wage and the price of is $X$ has been normalised to equal unity.

The factor market clearing conditions are as follows:

$Y=\left[1-\left(F\left(g\left(\omega, \omega^{*}\right)\right)\right] L_{S}\right.$

$a_{U X} X=L_{U}$

$a_{K Y} Y+a_{K X} X=K$

The right-hand side of equation (5) is the supply of skilled labour, which is endogenous due to the possibility of emigration. The right-hand side of equations (6) and (7), respectively, are the supply of unskilled labour and capital.

Eqs. (3)-(7) involve five endogenous variables: $w_{S}, w_{U}, r, Y$ and $X$. In the next section, we will examine the impact of a change in IPRs protection ( $\omega$ and $\omega^{*}$ ) on skilled wage premium.

\section{Skilled-unskilled wage inequality and IPR protection}

Totally differentiating (3)-(7) yields:

\footnotetext{
${ }^{6}$ See McAusland and Kuhn (2011) for the detailed explanation about migration cost $z$ and probability of migration $F(g)$.
} 
$\xi_{Y}^{S} \widehat{w}_{S}+\xi_{Y}^{K} \widehat{r}+\xi_{Y}^{K} \widehat{a}_{K Y}=\phi \widehat{\omega}+\phi^{*} \widehat{\omega}^{*}$

$\xi_{X}^{U} \widehat{w}_{U}+\xi_{X}^{U} \widehat{a}_{U X}+\xi_{X}^{K} \widehat{r}+\xi_{X}^{K} \widehat{a}_{K X}=0$

$\widehat{Y}=\varepsilon_{\omega}^{Y} \widehat{\omega}+\varepsilon_{\omega^{*}}^{Y} \widehat{\omega}^{*}$

$\widehat{a}_{U X}+\widehat{X}=0$

$\theta_{K}^{Y} \widehat{Y}+\theta_{K}^{Y} \widehat{a}_{K Y}+\theta_{K}^{X} \widehat{X}+\theta_{K}^{X} \widehat{a}_{K X}=0$

where $\wedge$ on top of a variable represents percentage change in that variable, $\phi$ and $\phi^{*}$ are the market shares of domestic and the foreign countries $\left(\phi+\phi^{*}=1\right), \varepsilon_{\omega}^{Y}$ and $\varepsilon_{\omega^{*}}^{Y}$ are the elasticity of innovation good $Y$ with respect to IPR protection.

For firms in sector $X, \xi_{X}^{U} \widehat{a}_{U X}+\xi_{X}^{K} \widehat{a}_{K X}=0$. However, in the case of the innovation sector, $Y$, the input coefficient of skilled labour is fixed and profit earned from innovation is protected by the IPR regimes, hence, $\xi_{Y}^{K} \widehat{a}_{K Y}=\phi \widehat{\omega}+\phi^{*} \widehat{\omega}^{*}$. Furthermore, we define the elasticity of substitution between unskilled labour and capital in the normal good sector $\sigma_{X}=\left(\widehat{a}_{K X}-\widehat{a}_{U X}\right) /\left(\widehat{w}_{U}-\widehat{r}\right)$, which is positive. The link between IPR protection and skilled-unskilled wage inequality as follows ${ }^{7}$ : the wages of skilled labour.

However, in this process, demand for capital in sector Yincreases, which, in the context of fixed capital supply, reduces the capital used in normal sector and in turn increases the unskilled wage rate too. Given the innovation sector is capital intensive $\left(\xi_{X}^{K} \xi_{Y}^{S}<\xi_{Y}^{K} \xi_{X}^{U}\right)$, the increase in the unskilled wage rate, is relatively larger, and this reduces the skilledunskilled wage inequality.

We now investigate the impact of an increase in IPR protection in the foreign country on skilled-unskilled wage inequality in the source country.

Proposition 2. If IPR protection in the recipient country $(R)$ increases, the skilled-unskilled wage inequality in the source country $(S)$ will increase when the output effect is stronger than the revenue effect, and vice versa.

Proof: See Appendix B.

The impact of an increase in IPRs protection in the recipient country on skilled-unskilled wage inequality in source country can also be broken down into output and revenue channels (see equation (13)). However, in this case, the two effects work in different directions. Higher IPR protection in country $R$ increases the revenue of inventors located in country $S$ from sales in the foreign country $\left(\phi^{*} / \xi_{Y}^{K}>0\right)$. In other words, revenue effect is positive. At the same time, because of the stricter IPRs scheme implemented in country $R$, there is an increase in the expected revenue

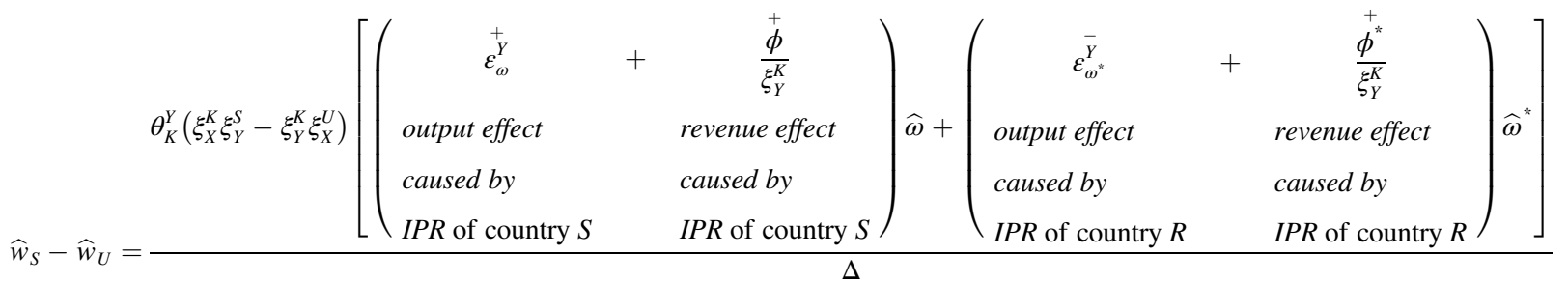

$\widehat{r}=\frac{\theta_{K}^{Y} \xi_{Y}^{S} \xi_{X}^{U}\left[\left(\varepsilon_{\omega}^{Y}+\frac{\phi}{\xi_{Y}^{R}}\right) \widehat{\omega}+\left(\varepsilon_{\omega^{*}}^{Y}+\frac{\phi^{*}}{\xi_{Y}^{R}}\right) \widehat{\omega}^{*}\right]}{\Delta}$

where $\quad \varepsilon_{\omega}^{Y}=-\frac{L_{s} F_{g} g_{\omega}}{Y / \omega}>0, \varepsilon_{\omega^{*}}^{Y}=-\frac{L_{s} F_{g} g_{\omega^{*}}}{Y / \omega^{*}}<0, F_{g}=\frac{d F}{d g}>0, g_{\omega}=\frac{\partial g}{\partial \omega}<0$ and $g_{\omega}=\frac{\partial g}{\partial \omega^{*}}>0 \Delta=\theta_{K}^{X} \xi_{Y}^{S} \sigma_{X}>0$

Using equation (13), we first examine the impact of a change in IPR protection on skilled-unskilled wage inequality in the source country.

Proposition 1. If IPR protection in source country $(S)$ increase, ceteris paribus, its own skilled-unskilled wage inequality will decrease.

Proof: See Appendix B.

The impact of a change in IPRs protection in country $S$ on its wage premium of skilled labour can be broken down into two channels. The first channel is via output effect due to labour mobility which is pos$\operatorname{itive}\left(\varepsilon_{\omega}^{Y}=-\frac{L_{s} F_{g} g_{\omega}}{Y / \omega}>0\right)$, that is, the higher IPRs protection of the source country decreases the expected revenue gap $g\left(\omega, \omega^{*}\right)$ and hence reduces the outflow of skilled labour, which increases the domestic output of innovation goods. The second channel is revenue effect $\left(\phi / \xi_{Y}^{K}>0\right)$ where higher domestic IPRs protection increases the revenue from the domestic market. These two channels work in the same direction: the innovation sector output increases and the revenue to inventors from the domestic market also increases. Higher IPRs protection in country Swill increase

\footnotetext{
7 The derivation, see Appendix A.
}

gap, which increases the outflow of skilled labour thereby decreasing the output of the innovation $\operatorname{good}\left(\varepsilon_{\omega^{*}}^{Y}=-\frac{L_{s} F_{g} g_{\omega^{*}}}{Y / \omega^{*}}<0\right)$ in country $S$, that is, output effect is negative.

If the negative output effect is stronger than the positive revenue effect, higher IPRs protection in country $R$ will decrease return to the skilled labour in country $S$. That is, the wages of the skilled labour-force will decrease. In this process, more capital will flow into normal sector and in turn decrease the wage of unskilled labour too. Similar to the analysis for Proposition 1, because innovation sector is capital intensive, there is a relatively larger decrease in the unskilled wage rate, which increases skilled-unskilled wage inequality. In contrast, if the revenue effect surpasses the output effect, the wages of both skilled and unskilled labour will increase, and wage inequality will decrease due to the fixed capital supply and the different intensity of production factors for different sectors.

Propositions 1 and 2 crucially depend on the fact that an increase in IPR protection in either country increases the return to capital in the home country, as shown in equation (14).

\section{Conclusion}

Wage inequality has been observed in both developed and developing economics (Autor and Dorn, 2013). The explanations for wage premium for skilled labour, broadly include technological development and international trade (Krugman, 2000). There are a number of studies that attempted to identify the determinants of skilled-unskilled wage inequality. For example, Saint-Paul (2008) and Goldin and Katz (2009) 
investigated the effect of innovation on wage inequality, while Zhang (2012) investigated the short-term effect of factor mobility and Anwar (2010); Anwar et al. (2013) highlighted the role of off-shoring on wage inequality. This paper extends the existing literature by exploring the role of intellectual property rights (IPRs) protection - an important policy tool. Specifically, we use a two-sector model of a small open economy that produces one normal (manufactured) good and one innovation good. The innovation good is produced by skilled labour and capital, whereas the normal good is produced by unskilled labour and capital. Skilled workers are the inventors who can sell the innovation good to both domestic and foreign consumers. As the innovation can be easily copied, both domestic and foreign governments take steps to protect IPRs.

We find that there are two channels through which IPRs protection effects the skilled-unskilled wage inequality in the source country of skilled labour: output effect and revenue effect. An increase in IPRs protection in the source country decreases the skilled-unskilled wage inequality because both revenue and output effects move in the same direction. However, in the case of an increase in IPRs protection in the foreign country, the output and revenue effects move in the opposite direction. Therefore, the impact of IPRs protection of the recipient country on wage inequality of the source country depends on which effect is dominant - output effect or revenue effect.

This paper offers an interesting explanation of change in wage inequality from the perspective of IPRs protection, an important government' policy instrument. There are some far reaching policy implications from this research. First, policy makers must acknowledge that IPRs should be a consideration when attempting to understand migration trends, one of the crucial explanations for wage inequality. Second, it is important to take the linkage between different sectors into account when setting the IPRs protection policies. Lastly, besides their own IPRs policies, the policy makers must also take their counterparts' policies on IPRs into account. As our study shows, a country's IPRs protection may have impact on its own and other countries wage inequality.

The consequences of IPRs protection for skill-biased labour mobility and wage premiums are only beginning to receive academic attention. With respect to further work, it will be worthwhile to consider the interaction of IPR protection with technological development given that innovation activities often lead to growing productivity of other sectors (Nemlioglu and Mallick, 2017). Though the existing literature suggested a higher capital intensity in the innovation sector compared to the normal sector, with technology development and globalization, changes in endowment intensity in the innovation sector could work along with IPRs protection. A further study that addresses changes in factor intensity of the innovation sector in the long-run is necessary. In addition, the mobility of unskilled labour caused by changes in wage inequality, which is led by IPRs protection warrants further studies.

\section{Acknowledgements}

The authors thank Professor Sushanta Mallick for encouragement and three referees for comments and suggestions. Jingjing Zhang appreciates funding supported by Government Audit Research Foundation of Nanjing Audit University, China. Riccardo Leoncini acknowledges the financial support by the Agreement CNR/NSC, Two Year Programme 2014-15. Yingyi Tsai gratefully acknowledges the funding support from Ministry of Science and Technology, Taiwan under research grant No.: MOST 1032923-H-390-001-MY2, which facilitates completion of this paper.

Appendices.

Appendix A. Link between IPRs protection and skilled-unskilled wage inequality

We make use of the following relationships.

$\widehat{a}_{K Y}=\frac{\phi \widehat{\omega}+\phi^{*} \widehat{\omega}^{*}}{\xi_{Y}^{K}}$

$\widehat{a}_{U X}=-\xi_{X}^{K} \sigma_{X}\left(\widehat{w}_{U}-\widehat{r}\right)$

$\widehat{a}_{K X}=\xi_{X}^{U} \sigma_{X}\left(\widehat{w}_{U}-\widehat{r}\right)$

Replacing (10), (11) into (12) and (A.1)-(A.3) into (8), (9) and (12), yields:

$\xi_{Y}^{S} \widehat{w}_{S}+\xi_{Y}^{K} \widehat{r}=0$

$\xi_{X}^{U} \widehat{w}_{U}+\xi_{X}^{K} \widehat{r}=0$

$\theta_{K}^{X} \sigma_{X}\left(\widehat{r}-\widehat{w}_{U}\right)=\theta_{K}^{Y}\left[\varepsilon_{\omega}^{Y} \widehat{\omega}+\varepsilon_{\omega^{*}}^{Y} \widehat{\omega}^{*}+\frac{\phi \widehat{\omega}+\phi^{*} \widehat{\omega}^{*}}{\xi_{Y}^{K}}\right]$

where $\varepsilon_{\omega}^{Y}=-\frac{L_{s} F_{g} g_{\omega}}{Y / \omega}>0, \varepsilon_{\omega^{*}}^{Y}=-\frac{L_{s} F_{g} g_{\omega^{*}}}{Y / \omega^{*}}<0, F_{g}=\frac{d F}{d g}>0, g_{\omega}=\frac{\partial g}{\partial \omega}<0$ and $g_{\omega}=\frac{\partial g}{\partial \omega^{*}}>0$

Eq. (A.4)-(A.6) can be used to examine the between IPR protection and skilled-unskilled wage inequality as shown in (13) and (14).

Appendix B. Proof of propositions

Proof of Proposition 1

Since innovation sector is capital intensive compared to normal sector, we have $\xi_{X}^{K} \xi_{Y}^{S}<\xi_{Y}^{K} \xi_{X}^{U}$. Assuming that IPRs protection in the foreign country is fixed $\left(\widehat{\omega}^{*}=0\right)$, the impact of higher IPR protection in the home country $(\widehat{\omega}>0)$ is determined by $\left(\varepsilon_{\omega}^{Y}+\frac{\phi}{\xi_{Y}^{K}}\right)$. As both $\varepsilon_{\omega}^{Y}$ and $\frac{\phi}{\xi_{Y}^{R}}$ are positive, the impact of 
IPR protection in the home country on inequality is negative $\left(\widehat{w}_{S}-\widehat{w}_{U}<0\right)$.

Proof of Proposition 2

Assuming that home country IPR protection is fixed $(\widehat{\omega}=0)$, the impact of higher IPR protection in the foreign country $\left(\widehat{\omega}^{*}>0\right)$ on skilled-unskilled wage inequality in the home country is determined by $\left(\varepsilon_{\omega^{*}}^{Y}+\frac{\phi^{*}}{\xi_{Y}^{K}}\right)$. Since the associated output effect $\varepsilon_{\omega^{*}}^{Y}$ is negative but the revenue effect $\frac{\phi^{*}}{\xi_{Y}^{k}}$ is positive, the overall impact of the foreign country's IPR protection on the skilled-unskilled wage inequality in the home country depends on the relative size of the two effects.

\section{References}

Acemoglu, D., 2002. Technical change, inequality, and the labor market. J. Econ. Lit. 40 (1), 7-72.

Agrawal, A., Kapur, D., McHale, J., Oettl, A., 2011. Brain drain or brain bank? The impact of skilled emigration on poor-country innovation. J. Urban Econ. 69 (1), 43-55.

Antras, P., Helpman, E., 2004. Global sourcing. J. Polit. Econ. 112 (3), 552-580.

Anwar, S., 2010. Wage inequality, increased competition, and trade liberalization: short run vs long run. Rev. Int. Econ. 18 (3), 574-581.

Anwar, S., Sun, S., Valadkhani, A., 2013. International outsourcing of skill intensive tasks and wage inequality. Econ. Model. 31, 590-597.

Anwar, S., Sun, S., 2015. Taxation of labour income and the skilled-unskilled wage inequality. Econ. Model. 47, 18-22.

Autor, D.H., Dorn, D., 2013. The growth of low-skill service jobs and the polarization of the US labor market. Am. Econ. Rev. 103 (5), 1553-1597.

Autor, D.H., Katz, L.F., Krueger, A.B., 1998. Computing inequality: have computers changed the labor market? Q. J. Econ. 113 (4), 1169-1213.

Berman, E., Machin, S., 2000. Skill-biased technology transfer around the world. Oxf. Rev. Econ. Policy 16 (3), 12-22.

Bottini, N., Ernst, C., Luebker, M., 2007. Offshoring and the Labour Market: what Are the Issues? Internat. Labour Office.

Chu, A.C., Peng, S.K., 2011. International intellectual property rights: effects on growth, welfare and income inequality. J. Macroecon. 33 (2), 276-287.

Commander, S., Kangasniemi, M., Winters, L.A., 2004. The Brain Drain: Curse or Boon? a Survey of the Literature' Challenges to Globalization: Analyzing the Economics'. University of Chicago Press, pp. 235-278.

Diwan, I., Rodrik, D., 1991. Patents, appropriate technology, and North-South trade. J. Int. Econ. 30 (1), 27-47.

Docquier, F., Rapoport, H., 2008. Skilled Migration: the Perspective of Developing Countries.

Eden, M., Gaggl, P., 2014. The Substitution of ICT Capital for Routine Labor: Transitional Dynamics and Long-run Implications. World Bank Group Policy Research Working Paper Series, No. 7487.

Gaggl, P., Wright, G.C., 2017. A short-run view of what computers do: evidence from a UK tax incentive. Am. Econ. J. Appl. Econ. 9 (3), 262-294.

Goldin, C., Katz, L., 2009. The Race between Education and Technology. The Belknap Press of Harvard University Press, Cambridge, Massachusetts.

Grossman, G.M., Lai, E.L.C., 2004. International protection of intellectual property. Am Econ. Rev. 94 (5), 1635-1653.

Grubel, H.B., Scott, A.D., 1966. The international flow of human capital. Am. Econ. Rev. $56(1 / 2), 268-274$.

ILO, 2016. Global Wage Report 2016/17. Wage Inequality in the Workplace. International Labour Office, Geneva.

Katz, L.F., Murphy, K.M., 1992. Changes in relative wages, 1963-1987: supply and demand factors. Q. J. Econ. 107 (1), 35-78.

Kremer, M., Maskin, E., 2006. Globalization and Inequality. Working Paper. Harvard University, Department of Economics.

Kristal, T., Cohen, Y., 2015. What do computers really do? Computerization, fading paysetting institutions and rising wage inequality. Res. Soc. Stratif. Mobil. 42, 33-47.
Krugman, P.R., 2000. Technology, trade and factor prices. J. Int. Econ. 50 (1), 51-71.

Kurokawa, Y., 2014. A survey of trade and wage inequality: anomalies, resolutions and new trends. J. Econ. Surv. 28 (1), 169-193.

Lai, E.L.C., Qiu, L.D., 2003. The North's intellectual property rights standard for the South? J. Int. Econ. 59 (1), 183-209.

Lemieux, T., 2008. The changing nature of wage inequality. J. Popul. Econ. 21 (1), 21-48.

Li, X., Zhou, Y., 2013. An economic analysis of remittance of unskilled migration on skilled-unskilled wage inequality in labor host region. Econ. Model. 33, 428-432.

McAusland, C., Kuhn, P., 2011. Bidding for brains: intellectual property rights and the international migration of knowledge workers. J. Dev. Econ. 95 (1), 77-87.

Mallick, S.K., Sousa, R.M., 2017. The skill premium effect of technological change: new evidence from the US manufacturing sector. Int. Labour Rev. 156 (1), 113-131.

Marouani, M.A., Nilsson, B., 2016. The labor market effects of skill-biased technological change in Malaysia. Econ. Model. 57, 55-75.

Maskin, E., 2015. Why Haven't global markets reduced inequality in emerging economies? World Bank Econ. Rev. 29 (Suppl.), S48-S52.

Mondal, D., Gupta, M.R., 2008. Innovation, imitation and intellectual property rights: introducing migration in Helpman's model. Jpn. World Econ. 20 (3), 369-394.

Naghavi, A., Strozzi, C., 2015. Intellectual property rights, diasporas, and domestic innovation. J. Int. Econ. 96 (1), 150-161.

Nemlioglu, I., Mallick, S.K., 2017. Do managerial practices matter in innovation and firm performance Relations? New evidence from the UK. Eur. Financ. Manag. https://doi. org/10.1111/eufm.12123.

OECD, 2011. Divided We Stand: Why Inequality Keeps Rising. OECD Publishing.

OECD, 2013. Supporting Investment in Knowledge Capital, Growth and Innovation. OECD Publishing.

OECD, 2014a. OECD Science, Technology and Industry Outlook 2014. OECD Publishing. OECD, 2014b. National Intellectual Property Systems, Innovation and Economic Development: with Perspectives on Colombia and Indonesia. OECD Publishing.

Pi, J., Zhou, Y., 2012. Public infrastructure provision and skilled-unskilled wage inequality in developing countries. Labour Econ. 19 (6), 881-887.

$\mathrm{Pi}, \mathrm{J}$., Zhou, Y., 2014. Institutional quality and skilled-unskilled wage inequality. Econ. Model. 35, 356-363.

Pi, J., Zhou, Y., 2015. Rural property rights, migration, and welfare in developing countries. B. E. J. Econ. Anal. Policy 15 (3), 997-1030.

Rosen, S., 1981. The economics of superstars. Am. Econ. Rev. 71 (5), 845-858.

Saint-Paul, G., 2008. Innovation and Inequality: How Does Technical Progress Affect Workers? Princeton University Press, Princeton.

Srour, I., Taymaz, E., Vivarelli, M., 2013. Skill-biased Technological Change and Skillenhancing Trade in Turkey: Evidence from Longitudinal Microdata, No. 7320. Institute for the Study of Labor, IZA.

UNDP, 2013. Humanity Divided: Confronting Inequality in Developing Countries. United Nations Development Programme, Bureau for Development Policy, New York.

World Bank, 2016. World Development Report 2016: Digital Dividends. World Bank, Washington.

Zhang, J., 2012. Inflow of labour, producer services and wage inequality. Econ. Lett. 117 (3), 600-603.

Zhang, J., 2013. Factor mobility and skilled-unskilled wage inequality in the presence of internationally traded product varieties. Econ. Model. 30, 579-585. 